\title{
Pengabdian pada Masyarakat Kegiatan Perencanaan dan Pelaksanaan Gapura Universitas Tribhuwana Tunggadewi di RW 01, RW 06, RW 08 Kelurahan Tlogomas Malang
}

\author{
Fifi Damayanti ${ }^{1}$, Meidha Ayu Sitrina ${ }^{2}$, Abdur Rohim Sidiq ${ }^{3}$ \\ 1,2,3 Program Studi Teknik Sipil, Fakultas Teknik, Universitas Tribhuwana Tunggadewi Malang \\ ${ }^{1}$ fifidamayanti197408@yahoo.co.id. HP. 081334729592 \\ ${ }^{2}$ meidhaayu_sitrina@yahoo.co.id. HP. 089627005824 \\ ${ }^{3}$ him.stegen@yahoo.com. HP. 085248506660
}

\begin{abstract}
ABSTRAK
Universitas Tribhuwana Tunggadewi (Unitri) merupakan salah satu perguruan tinggi swasta yang secara geografis terletak di Jl. Telaga Warna blok C, Tlogomas Malang. Letak kampus yang masuk wilayah pemukiman warga menjadi kendala bagi calon mahasiswa dan masyarakat awam yang belum mengetahui letak Universitas Tribhuwana Tunggadewi dengan baik. Adapun permasalahan lain karena tidak tersedianya akses penunjuk jalan menuju kampus tersebut. Hal inilah yang menginsipirasi dilaksanakannya pengabdian masyarakat berupa perencanaan dan pelaksanaan gapura Unitri sebagai penunjuk arah sekaligus ikon kampus Universitas Tribhuwana Tunggadewi. Gapura ini memiliki dimensi sebagai berikut; luas alas $1,33 \times 1,04 \mathrm{~m}$, tinggi $6,65 \mathrm{~m}$, jumlah undakan 38 buah, sama untuk kedua sisinya. RAB gapura Unitri membutuhkan dana Rp. 41.900.000, dengan waktu pelaksanaan 2 bulan. Adapun tujuan pengabdiaan masyarakat ini adalah ; (1) Pembangunan gapura Unitri sebagai akses penunjuk jalan menuju kampus Universitas Tribhuwana Tunggadewi. (2) Menciptakan bangunan yang memiliki nilai estetika dan menerapkan konsep kerajaan Majapahit. (3) Menciptakan eksistensi kampus dan beberapa RW terkait serta dapat digunakan sebagai media promosi. Metode yang digunakan adalah metode difusi iptek. Pengabdian masyarakat ini menghasilkan sebuah produk desain gapura Unitri dan diperoleh kesimpulan sebagai berikut ; (1) Tersedianya akses penunjuk jalan menuju kampus Unitri. (2) Menciptakan bangunan yang memiliki nilai estetika dan menerapkan konsep Majapahit, yang merupakan identitas Unitri. (3). Digunakan sebagai media promosi kampus dan kepentingan RW terkait.
\end{abstract}

Kata kunci : gapura; unitri; ikon

\section{ABSTRACT}

Tribhuwana Tunggadewi University (Unitri) is one of the higher education institutions that is geographically located at Telaga Warna street blok C, Tlogomas Malang. Location of the campus that include in the residential area was obstacle for prospective students and the general public who do not know well the location of Tribhuwana Tunggadewi University. As for other problems because of the unavailability access to the road guide to that located. This is what inspires the implementation of community service in the form of planning and implementing the Gate Unitri as a guide and Unitri icon. Gate Unitri has the use dimensions ; base area $1.33 \times 1.04 m$, height $6.65 \mathrm{~m}$, number of steps 38, same for both sides. RAB Gate Unitri needs Rp. 41,900,000.00, with a execution time of 2 months. The purpose of this community service is ; (1) Archway Construction Unitri is the access guide to Unitri. (2) Creating buildings that have aesthetic value and applying 
the Unitri concept . (3) Creating the existence of campuses and some $R W$ related and can be used as promotional media. The author use science and technology diffusion method. This community service produces a gate design of Unitri. The implementation of community service is concluded as follows; (1) The availability of access to the road guide to Unitri. (2). The success of applying the concept of the Majapahit kingdom was in accordance with the name identity of the University of Tribhuwana Tunggadewi. (3). Maked as media promotion of campus and interests of related $R W$.

Keywords : gate; unitri; icon

\section{PENDAHULUAN}

Universitas Tribhuwana Tunggadewi (Unitri) merupakan salah satu perguruan tinggi swasta di Jawa Timur, secara geografis terletak di Jl. Telaga Warna blok C, Tlogomas Malang. Nama Universitas terinsipirasi dari nama Tribhuwana Wijayatunggadewi merupakan penguasa ketiga dari kerajaan Majapahit, memerintah di tahun 1328-1351. Dari prasasti Singasari (1351) diketahui gelar abhisekanya ialah Sri Tribhuwana tunggadewi Maharajasa Jaya wisnuwardhani. Nama asli Tribhuwana Wijayatunggadewi adalah Dyah Gitarja.

Tribhuwana Wijayatunggadewi merupakan putri dari Raden Wijaya dan Gayatri. Memiliki adik kandung bernama Dyah Wiyat dan kakak tiri bernama Jayanagara. Pada masa kekuasaan Jayanegara (11309-1328) ia diangkat sebagai penguasa bawahan di Jiwana bergelar Bhre Kahuripan. Menurut Nagarakretagama, Tribhuwana naik takhta tahun 1329 atas perintah ibunya (Gayatri) untuk menggantikan Jayanagara yang meninggal tahun 1328 . Ketika Gayatri meninggal dunia tahun 1350, pemerintahan Tribhuwana pun berakhir pula. [1]

Nama Universitas Tribhuwana Tunggadewi telah populer di kalangan masyarakat luas, sehingga kampus ini terus meningkatkan fasilitas dan mutu akademik untuk memenuhi semboyannya sebagai universitas berbasis kerakyatan dan berkompeten. Hal inilah yang menjadi daya tarik tersendiri bagi calon mahasiswa dari seluruh nusantara untuk mendaftarkan diri di Universitas Tribhuwana Tunggadewi secara berbondong-bondong setiap tahunnya.

Letak kampus yang masuk wilayah pemukiman warga tentu menjadi kendala tersendiri bagi calon mahasiswa dan masyarakat awam yang belum mengetahui letak Unitri (Universitas Tribhuwana Tunggadewi). Adapun permasalahan lain yaitu tidak tersedianya akses penunjuk jalan menuju Universitas Tribhuwana Tunggadewi. Hal ini kemudian menginspirasi dilakukannya pengabdian masyarakat berupa perencanaan dan pelaksanaan gapura sebagai penunjuk arah sekaligus ikon kampus tersebut.

Fokus kegiatan pengabdian masyarakat dimulai dari proses desain hingga pelaksanaan proyek. Untuk ide desain gapura, mengusung konsep Majapahit. Alasan penggunaan konsep tersebut, telah dijelaskan pada paragraf sebelumnya tentang sejarah nama Universitas Tribhuwana Tunggadewi. Diharapkan konsep tersebut mampu memberi kesan kejawen yang kental dengan nilai kultur budaya pada kampus Unitri. 
Lokasi kegiatan pengabdian masyarakat berada di J1. Batu Permata dan dilaksanakan oleh mitra kerja dari Universitas Tribhuwana Tunggadewi sendiri. Adapun wilayah warga yang menggunakan akses jalan menuju kampus Unitri meliputi RW 01, RW 06, RW 08, sehingga dalam pelaksanaan gapura dicantumkan pula nomor ketiga RW tersebut [2].

Tujuan dilaksanakan pengabdian masyarakat adalah; (1). Pembangunan Gapura Unitri sebagai akses penunjuk jalan menuju kampus Universitas Tribhuwana Tunggadewi.

Menciptakan bangunan yang memiliki nilai estetika dan menerapkan konsep Majapahit, yang merupakan identitas Universitas Tribhuwana Tunggadewi. (3). Menciptakan eksistensi kampus dan rw terkait sehingga dapat digunakan sebagai media promosi Universitas Tribhuwana Tunggadewi maupun lingkungan sekitar.

\section{METODE KEGIATAN}

\subsection{Metode Difusi Iptek}

Difusi Iptek adalah teori tentang bagaimana sebuah ide dan teknologi baru tersebar dalam sebuah kebudayaan [2]. Difusi Iptek adalah kegiatan pengabdian masyarakat yang menghasilkan produk bagi konsumen baik internal maupun eksternal. Pengabdian masyarakat ini menghasilkan sebuah produk desain gapura Universitas Tribhuwana Tunggadewi.

\subsection{Urutan Pelaksanaan Proyek}

Sebelum proyek gapura Universitas Tribhuwana Tunggadewi dilaksanakan, ada beberapa tahapan sistematis yang dilakukan oleh penulis, dengan tujuan proses dan hasilnya nanti sesuai dengan apa yang telah direncanakan.

Tabel 1. Urutan Pelaksanaan Proyek

\begin{tabular}{ll}
\hline No & \multicolumn{1}{c}{ Nama Kegiatan } \\
\hline 1 Survey Lokasi dan Pengukuran & Selesai Dilakukan \\
2 Desain Utama & Selesai Dilakukan \\
3 Revisi Desain & Selesai Dilakukan \\
4 Desain Akhir dan Penentuan Bahan & Selesai Dilakukan \\
5 Penyusunan Rab, Time Schedule dan Metode Pelaksanaan & Selesai Dilakukan \\
\hline
\end{tabular}

\section{KARYA UTAMA}

\subsection{Analisis Desain Gapura}

Analisis desain gapura mengangkat konsep Majapahit, hal ini didasarkan pada nama Unitri yang mengambil nama seorang putri sekaligus penguasa ketiga di kerajaan Majapahit, dia memerintah tahun 1328- 351. Dari prasasti Singasari (1351) diketahui gelar Abhisekanya ialah Sri Tribhuwanottunggadewi Maharajasa Jayawisnuwardhani [1].

\subsection{Dimensi Gapura}

Dimensi Gapura sebagai berikut; luas alas $1,33 \times 1,04 \mathrm{~m}$, tinggi $6,65 \mathrm{~m}$, jumlah undakan $38 \mathrm{bh}$, sama untuk kedua sisinya. Tinggi plang pertama $4,84 \mathrm{~m}$, tinggi plang kedua $7,13 \mathrm{~m}$ dan lebar jalan $8,24 \mathrm{~m}$. Undakan dasar memiliki ketebalan $0,10 \mathrm{~m}$, undakan tengah memiliki ketebalan $0,25 \mathrm{~m}$. Dilanjutkan dengan ruas atas Gapura yang memiliki variasi semakin kecil dan mengerucut keatas layaknya piramid, tebal tiap undakan pada ruas atas adalah $5 \mathrm{~cm}$.

\subsection{Spesifikasi Material dan Bahan}

Spesifikasi material dan alat yang digunakan adalah; bata merah, semen, 
pipa besi anti karat $\varnothing 0,10 \mathrm{~m}$ untuk pembentuk tiang penyangga, profil besi anti karat model lempeng lebar $0,55 \mathrm{~m}$ untuk lempeng nama, tulangan dirakit dengan besi $\mathrm{D} 10 \mathrm{~cm}$, sengkang $\mathrm{d} 6 \mathrm{~cm}$ yang kemudian diikat dengan kawat dendrat.

\subsection{Detail Enginnering Design}

Untuk finishing digunakan cat dinding hitam untuk badan Gapura, cat meni kuning, meni ungu, meni putih, meni merah untuk papan nama, 2 lampu taman, 2 lampu sorot ke arah tulisan. Kemudian alat yang digunakan adalah perancah, solder, tangga, alat pengaduk semen dan lain sebagainya. Untuk lebih lengkap dapat dilihat pada Detail Enginnering Design (DED) berikut.
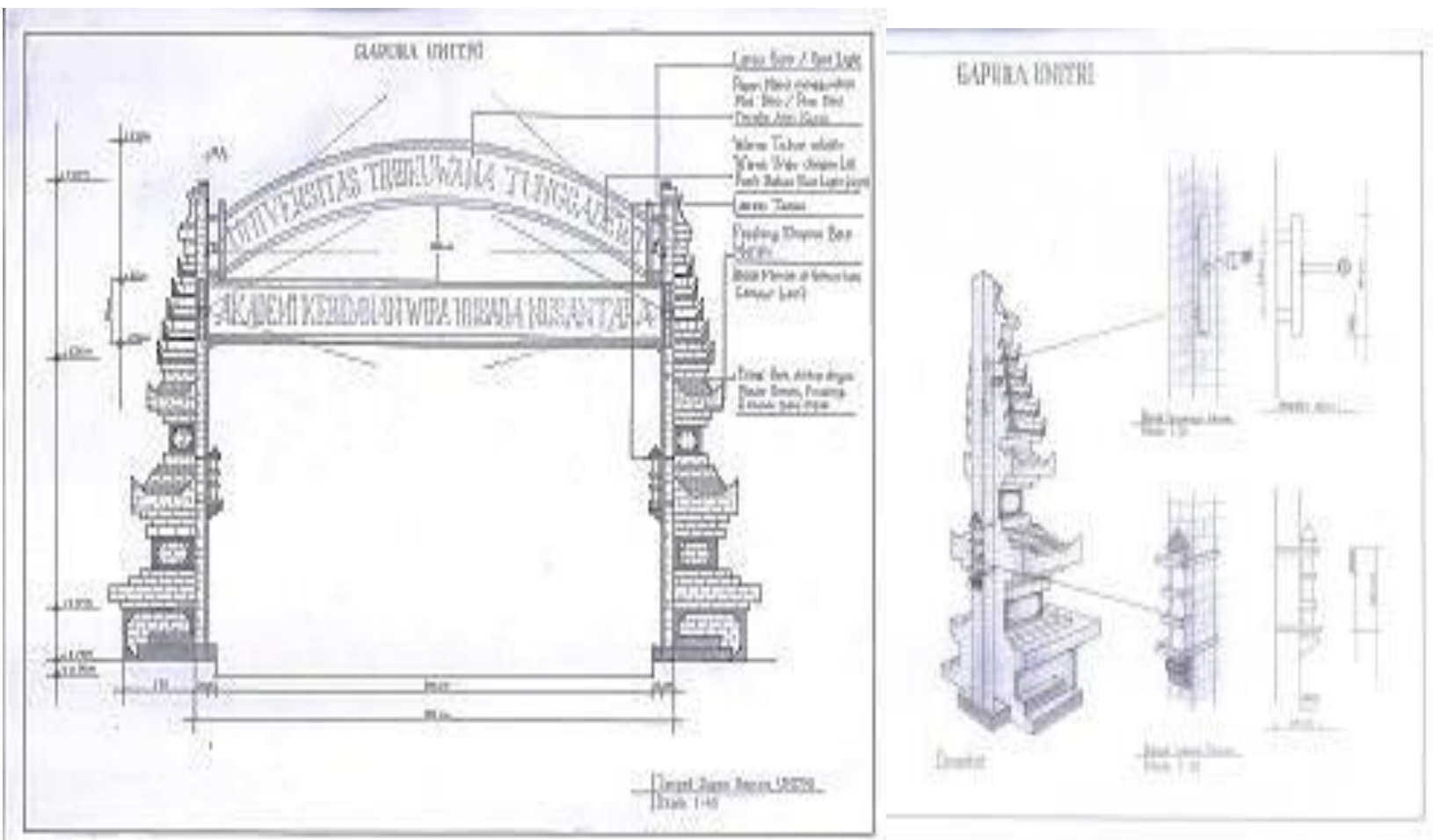

Gambar 1. DED Gapura Unitri

\subsection{Rencana Anggaran Biaya}

Rencana anggaran biaya (RAB) gapura Universitas Tribhuwana Tunggadewi menyesuaikan biaya yang telah disetujui oleh mitra kampus Unitri. Adapun RAB gapura tersebut adalah sebagai berikut.

\section{Tabel 2. RAB Gapura Unitri}

\begin{tabular}{cllr}
\hline No & \multicolumn{1}{c}{ Pekerjaan } & \multicolumn{2}{c}{ Jumlah Harga } \\
\hline 1 & Pekerjaan Persiapan & $\mathrm{Rp}$ & $2.334 .484,38$ \\
2 & Pekerjaan Tanah & $\mathrm{Rp}$ & $340.806,20$ \\
3 & Pekerjaan Pasangan & $\mathrm{Rp}$ & $16.048 .328,34$ \\
4 & Pekerjaan Plseteran & $\mathrm{Rp}$ & $4.754 .295,15$ \\
5 & Pekerjaan Beton & $\mathrm{Rp}$ & $9.721 .540,45$ \\
6 & Pekerjaan Pengecatan & $\mathrm{Rp}$ & $3.821 .464,07$ \\
7 & Pekerjaan Instalasi Listrik & $\mathrm{Rp}$ & $933.340,20$ \\
8 & Pekerjaan Lanscaping & $\mathrm{Rp}$ & $110.000,00$ \\
& & & \\
\hline & Jumlah Harga Konstruksi & $\mathrm{Rp}$ & $38.064 .258,79$ \\
& PPn 10\% & $\mathrm{Rp}$ & $3.806 .425,88$ \\
& Total Biaya Konstruksi & $\mathrm{Rp}$ & $41.870 .684,67$ \\
& Total Biaya Dibulatkan & $\mathrm{Rp}$ & $41.900 .000,00$ \\
\hline \multicolumn{2}{l}{ Terbilang : Empat Puluh Satu Juta Sembilan Ratus Ribu Rupiah } \\
\hline \multicolumn{2}{c}{}
\end{tabular}




\subsection{Time Schedule}

Time Schedule (Curve S) pelaksanaan Gapura Unitri adalah waktu yang dijadwalkan untuk pelaksanaan pembangunan Gapura mulai dari survey lokasi hingga selesai adalah selama 2 bulan. Adapun detail Curve $S$ dapat dilihat pada tabel berikut.

\section{Tabel 3. Curve $S$ Gapura Unitri}

\begin{tabular}{|c|c|c|c|c|c|c|c|c|c|c|c|}
\hline \multirow{2}{*}{ No } & & \multirow{2}{*}{ Uraian } & \multirow{2}{*}{ Bobot } & \multicolumn{4}{|c|}{ Agustus } & \multicolumn{4}{|c|}{ September } \\
\hline & & & & 1 & 2 & 3 & 4 & 5 & 6 & 7 & 8 \\
\hline I & Pekerjan Persiapan & & 1,58 & 1,58 & & & & & & & \\
\hline II & Pekerjaan Tanah & & 2,27 & 1,14 & 1,14 & & & & & & \\
\hline III & Pekerjaan Beton & & 31,68 & & 10,56 & 10,56 & 10,56 & & & & \\
\hline IV & Pekerjaan Pasangan & & 40,35 & & & & & 13,45 & 13,45 & & \\
\hline $\mathrm{v}$ & Pekerjan Plesteran & & 10,12 & & & & & & 5,06 & 5,06 & \\
\hline VI & Pekerjaan Pengecatan & & 10,12 & & & & & & & 5,06 & 5,06 \\
\hline VII & Pekerjan Instalasi Listrik & & 2,30 & & & & & & & & 2,30 \\
\hline \multirow[t]{3}{*}{ VIII } & Pekerjaan Lanscaping & & 1,58 & & & & & & & & 1,58 \\
\hline & & Jumlah Nilai Pekerjaan & 100,00 & 2,72 & 11,70 & 10,56 & 24,01 & 13,45 & 18,51 & 10,12 & 8,94 \\
\hline & & Komulatif Pekerjaan & & 2,72 & 14,41 & 24,97 & 48,98 & 62,43 & 80,94 & 91,06 & $\overline{100,0}$ \\
\hline
\end{tabular}

\subsection{Dokumentasi Pelaksanaan}

Pelaksanaan pembuatan dilapangan dilakukan sesuai dengan dokumen metode pelaksanaan yang telah dibuat dan disepakati. Adapun teknik pengumpulan data maupun foto-foto yang relevan dilaksanakan dengan turun ke lokasi setiap 7 hari sekali untuk mengambil foto tersebut. Foto-foto tersebut terdiri dari foto awal proyek yaitu lokasi proyek, foto proses proyek yaitu foto saat proyek berlangsung dan foto akhir proyek yaitu foto hasil proyek.

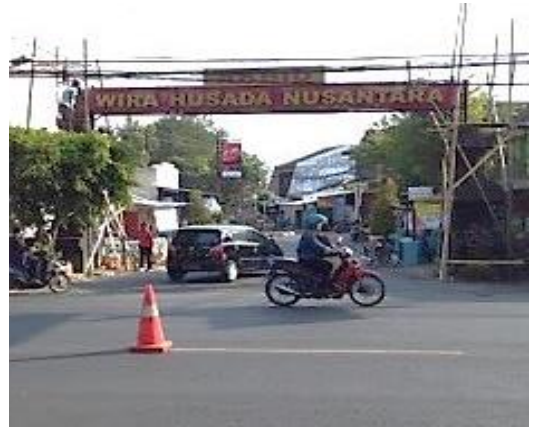

Gambar 2. Foto Lokasi Proyek

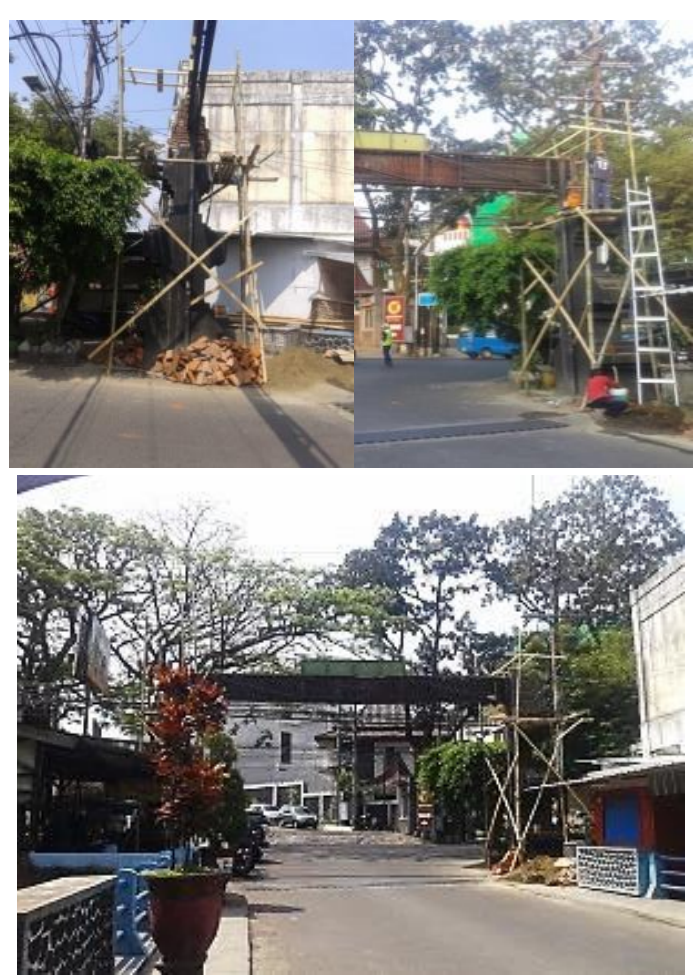

Gambar 3. Foto Proses Pelaksanaan Gapura Minggu ke-1, Minggu ke-4, Minggu ke-8

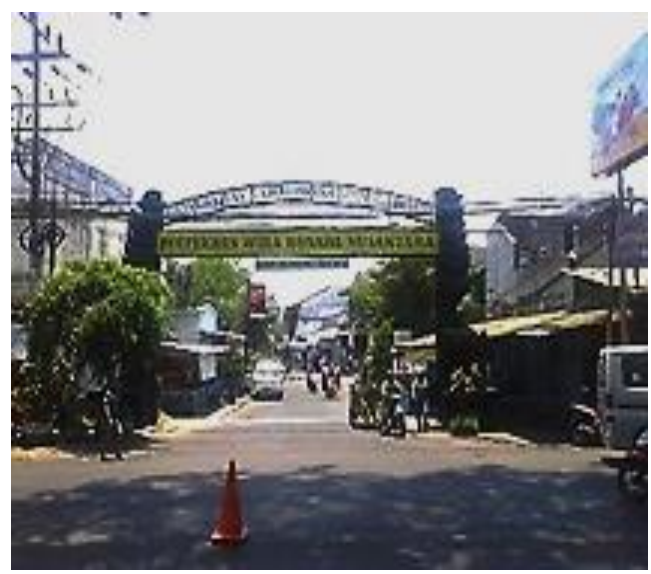

Gambar 4. Foto Akhir Proyek

\section{ULASAN KARYA}

\subsection{Keunggulan Karya}

Dari segi arsitektural, desain memiliki nilai estetika yang baik, telah mencerminkan nilai lokal dan menanamkan identitas kampus didalamnya. Dari segi kekuatan bangunan, bahan yang digunakan adalah bahanbahan yang kuat serta mudah didapatkan. 
Dari segi ekonomi, RAB pembuatan gapura Universitas Tribhuwana Tunggadewi tergolong ekonomis dengan nilai Rp. 41.900 .000

\subsection{Kelemahan Karya dan Tingkat Kesulitaan Pelaksanaan}

Lokasi pelaksanaan pembangunan gapura berada di lingkungan padat penduduk, yaitu banyaknya bangunan rumah masyarakat yang cukup menyulitkan proses perletakan material dan alat pembuatan gapura. Hal ini menyebabkan ukuran/ dimensi gapura tersebut tidak dapat disesuaikan dengan ukuran desain semula, yaitu merencanakan pembuatan gapura dengan dimensi yang lebih besar dengan tujuan agar lebih terekspos. Hal ini berpengaruh pada proses desain maupun pelaksanaan gapura Unitri, yaitu terjadi sedikit keterlambatan pada operasional penyesuaian Time Schedule dengan target awal metode pelaksanaan menjadi tidak tepat waktu.

\section{DAMPAK DAN MANFAAT KEGIATAN}

Masyarakat awam yang belum mengetahui akses menuju kampus Universitas Tribhuwana Tunggadewi menjadi paham dan lebih mudah untuk mengakses jalan menuju kampus tersebut, karena sudah tersedia petunjuk jalan. Kampus Unitri memiliki ikon yang berhasil diaplikasikan dalam dunia nyata serta melambangkan identitas nama Universitas Tribhuwana Tunggadewi. Dalam media promosi, memudahkan masyarakat awam dan calon mahasiswa baru untuk mencari letak kampus Unitri dan rw terkait. Sehingga lebih dikenal oleh masyarakat luas.

\section{KESIMPULAN}

Pelaksanaan gapura telah selesai dilaksanakan, sehingga ketercapaian target pengabdian masyarakat adalah sebagai berikut :

(1). Telah tersedianya akses penunjuk jalan menuju kampus Universitas Tribhuwana Tunggadewi, sehingga masyarakat awam mengetahui dan lebih mudah mengakses jalan menuju kampus tersebut.

(2). Keberhasilan menerapkan konsep kerajaan Majapahit sesuai dengan identitas nama Universitas Tribhuwana Tunggadewi, serta sebagai penambah nilai estetika bangunan penunjuk kampus.

(3). Gapura ini dapat digunakan sebagai media promosi dan kepentingan rw 1, rw 6 dan rw 8 yang bernilai positif. Hal ini berimbas pula pada Universitas Tribhuwana Tunggadewi dan wilayah sekitar menjadi lebih banyak dikenal oleh masyarakat awam.

Dalam pelaksanaan pembuatan Gapura, Time Schedule awal belum sesuai dengan metode pelaksanaan yang dibuat. DED dengan hasil dilapangan tingkat kemiripan sekitar $80 \%$. Untuk pengabdian selanjutnya, jika gapura ingin direnovasi, sebaiknya mempersiapkan dana operasional dan akomodasi yang lebih besar. Hal ini sangat penting, karena berhubungan dengan proses pengerjaan gapura, misalnya dimensi/ukuran gapura diperbesar, penggunaan bahan diharapkan bisa mengambil kelas yang lebih baik sehingga hasil gapura lebih bagus, dan melengkapi gapura dengan lampu atau 
ornamen lain yang lebih menarik perhatian bagi pengguna jalan untuk mencoba memasuki akses jalan menuju RW 1, RW 6, RW 8 dan kampus Universitas Tribhuwana Tunggadewi.

\section{PENGHARGAAN}

Penulis mengucapkan terima kasih yang sebesar-besarnya kepada pihak universitas yang telah memberikan kepercayaan pada jurusan teknik sipil Universitas Tribhuwana Tunggadewi untuk mendesain serta melaksanakan pembuatan gapura hingga finishing dalam rangka kegiatan pengabdian masyarakat ini. Penulis juga mengucapkan terima kasih kepada dosen-dosen Teknik Sipil Unitri yang telah berperan memberikan dukungan mulai dari pengawasan pembuatan hingga proyek gapura ini dapat terlaksana dengan baik. Tak lupa pula, penullis mengucapkan terima kasih kepada Bapak Aryadi Wardoyo selaku Lurah di Tlogomas Malang dan segenap masyarakat yang telah menyetujui serta memberikan saran untuk dibangunnya sebuah akses penunjuk jalan menuju kampus Universitas Tribhuwana Tunggadewi.

\section{DAFTAR PUSTAKA}

[1] Kontributor Wikipedia, "Tribhuwana Wijayatunggadewi," Wikipedia, EnsiklopediaBebas, https://id.wikipedia.o $\mathrm{rg} / \mathrm{w} /$ index.php?title=Tribhuwana_Wij ayatunggadewi\&oldid=13405246 (diaks es pada oktober 04, 2018).

[2] Mulyana, Slamet. (2008) peranan komunikasi dalam difusi teknolgi. Jurnal Smartek. 4 (3): 4-6.

[3] Roger, Everett. 1964. Diffusion of Innovations; edisi 5. New York. Simon \& Schuster Publisher (1): 34-35

[4] Wardoyo, Aryadi. Lurah tlogomas Malang. diwawancarai oleh penulis, Tlogomas, Malang, 28 september 2018 